\title{
Storytelling and Communal Singing: Effective Forms of Appropriation to Destabilize White Supremacy
}

\author{
Weiqiang Mao \\ School of Foreign Languages, Jiangus University, Zhenjian, China \\ Email: mcatalpa@hotmail.com
}

\begin{abstract}
Community features importantly both in the assertion of Afro-Americans' selfhood and the rehabilitation of their culture once lost in slavery. Toni Morrison believes that appropriation in the form of community storytelling and communal singing within black community is an effective instrument to destabilize white supremacy. This paper examines how community storytelling and communal singing works in Morrison's novel Beloved to rebuild African Americans' communal solidarity and start a discursive practice of cultural reconstruction.
\end{abstract}

Index Terms - appropriation, storytelling, communal singing, communal solidarity, cultural reconstruction

\section{APPROPRIATION, AN EFFECTIVE INSTRUMENT TO DESTABILIZE WHITE SUPREMACY}

The black community always plays an important role in the formation of Afro-Americans' selfhood. In Toni Morrison's Beloved, it is with help of the community that Sethe finally regains her sense of humanity and is able to start a new life. It is also within the black community that both Stamp Paid and Paul D have their humanity and subjectivity recognized. Sixo gets his humanity asserted but he fails to survive largely because he lets his selfhood rest upon the capriciousness of slave catchers and chooses to remain in isolation from the black community. Morrison seems to say that black Americans, in their refutation of the colonial discourse of slavery, should regard black community as a source for support and comfort.

Then, how can the Afro-American community rebuild their communal solidarity that is so important to their survival in the face of colonialism? To this question, Morrison answers by highlighting the importance and functions of individual figures in the community. Much, according to Morrison, depends on their ability to bring people together through discursive appropriation.

"Once upon a time there was an old woman. Blind. Wise. Or was it an old man? One day the woman is visited by some young people who seem to be bent on disproving her clairvoyance and...[I] have heard this story, or one exactly like it, in the lore of several cultures. In the version I know the woman is the daughter of slaves, black, American, and lives alone in a small house outside town." (Morrison, 1993) Thus begins Morrison's "Nobel Lecture". Morrison describes a scene in which the old woman is questioned by some young people from the city about how is the bird one of them claims to hold. To Morrison herself, the bird is language and storytelling, communal telling in particular, is a most convenient form for cultural production and preservation; and by conceiving an old blind black woman capable of magic being challenged by the young generation, possibly white Americans, Morrison argues a case about how black traditions shape and are reshaped by cultural realities.

Instead of expounding on how she has gained such prominence as a black American woman writer, Morrison's "Nobel Lecture" campaigns for the black presence within American cultural life and offers a blueprint for the reconstruction of Afro-American culture. Laying a special emphasis on the status of black women, Morrison (1993) maintains that the black woman as both life nurturer and culture producer has for too long been neglected by the dominant white American culture. Just like the young men "bent on disapproving her clairvoyance and showing her up for the fraud they believe she is" (Morrison, 1993), the dominant white American society has for too long relegated the black women to a position of invisibility.

By making a felicitous response to the young people's inquiry, Morrison believes, the old woman "shifts attention away from assertion of power to the instrument, i.e. the bird, through which that power is exercised", and confronts the young people with their responsibility. Morrison makes it clear that black invisibility is merely a "white figment" and white responsibility. She calls for the Afro-Americans to appropriate the "instrument" through which white supremacy is maintained.

The "instrument", Morrison explicitly points out, is the "oppressive language" ruthlessly engaged in its policing duties: "it has no desire or purpose other than maintaining the free range of its own narcotic narcissism, its own exclusivity and dominance" (Morrison, 1993). It is "a malign language of law-without-ethics, or language designed for the estrangement of minorities, hiding its racist plunder in its literary cheek."(Morrison, 1993) It must be rejected, 
altered and exposed because it permits no "new knowledge" or encourages no "mutual exchange of ideas". Morrison calls for the abandonment of racist and sexist use of language, and she looks to the agency promised of language that secures the Afro-American difference- "the way in which we are like no other life."(Morrison, 1993)

Appropriation is the key word in Toni Morrison's blueprint for African American cultural rehabilitation. Morrison argues that being able to choose is the prerequisite for cultural reconstruction because it is in the process of choosing words - picking up some words while discarding others - that a story is formulated and reformulated, heard and re-heard, with left-out spaces being filled and refilled with each telling among community members, white and black alike (Morrison, 1986, p.341). Being able to choose means that each of the individuals involved in the communal storytelling is a subject in the word-work (i.e. language user) instead of being subject of the word-work (i.e. object of language description), and that the narratives contrived in the telling will no longer prove incomprehensible among the community because it no longer "subscribed to dominant ideologies" (Schur, 2000, p. 456).

\section{STORYTELLING}

All the members in the black community in Beloved try very hard to reconstruct their own culture. In the novel, Morrison portrays the black women as the generating source and foundation for Afro-American cultural rehabilitation. Morrison believes that Afro-American cultural rejuvenation relies to a large extent on the rebuilding of communal solidarity. And to bring the black community together requires the efforts of strong willed men and women. In Beloved, Sethe is portrayed as one such figure. In the novel she is presented as a mother that fits well into the image Barber Hill Rigney (1991) has pictured for African American "Great Mother" (Rigney, 1991, p.70). She nurtures a big family and is trying by every means to protect the integrity of the household of 124 . But her greatness lies more in the fact "she reverses history, and resurrects that daughter she has killed" by appropriating the language of the colonizers (Rigney, 1991, p.70). Like the old woman in Morrison's "Nobel Lecture", Sethe is also challenged by several young people, one of whom is holding a bird. These young people include Denver, Beloved, Paul D and all other community members who have suffered less as compared to Sethe. The "bird" as instrument used by the "young people" to assert their sanity and humanity is the official history carried in the news clipping Stamp Paid has preserved. Though both Sethe and the old woman are engaged in the job of word-working and storytelling with the young people of their communities respectively, Sethe brings forth yet a communal awareness of the history of slavery that Morrison has left out in her "Nobel Lecture" but that proves of great importance for solidarity of the black community.

Sethe is aware that the "bird" in the form of news will have no life if it is left at the mercy of the challengers. It is because the language used in presenting the infanticide scene is sexist language and racist language that cuts out the black Americans' true experiences under slavery. As Paul D has noted, black Americans will not become the characters of news story until they have done something that can amuse white Americans. Therefore, much of the history about slavery is missing from American culture and the few documents available will necessarily present black Americans as racial others for the amusement of white Americans. For this reason, Paul D finds that the face in the news clipping is not Sethe's face (Morrison, 1987, p.155). On the other hand, the news clipping also deprives its protagonist both of her humanity and of her love for her killed daughter. Because of this, the history of slavery as a source for black cultural reconstruction must be revised. Just as Ashraf H. A. Rushdy (2001) argues, "the history of slavery is only a family secret that needs to be revised in order to be revered"(Rushdy, 2001, p. 2).

In Beloved, the historical rewriting takes the form of community storytelling. It is intended by Sethe to prove her ability both to love and to reason as a subject, and consequently disrupts the legitimacy of news-clipping story. Prior to Beloved's arrival at 124, Sethe tries to beat back the part of her memory that is too painful to remember. The only part of memory she would like to talk about is the part that concerns Denver because the only listener present at 124 is Denver. Although Denver is aware of Sethe's "cruelty" of killing her sister, she is pleased with the part of story about how Amy helped her mother on her way to Cincinnati and wants to know more about it. The asking and answering of questions concerning that past scene, together with Denver's telling of it later to Beloved helps confirm Sethe's selfhood as a loving mother and Denver's status as a loving daughter. More importantly, by referring to Denver in her stomach as antelope, Sethe is able to connect her body with the antelope dancing in traditional African culture. Sethe gives life to the news-clipping story by restaging the danger of being caught for her color and the hardship she has encountered on her way to freedom. Consequently, the family secret is revealed in the process of telling.

However, if we take into consideration the fact that Denver, as well as Sethe's other children, is only part of Sethe's body, the family-scale storytelling between Sethe and Denver constitutes no communal storytelling in the real sense. Rather, it is a monologue that leaves much of the historical incidents yearning for representation. Like the news-clipping story, the story constituted by Sethe and Denver lacks the vigor that the woman in Morrison's "Nobel Lecture" is seeking after.

It is imperative then for Sethe to seek trustworthy listeners and storytellers from outside to move her telling and retelling of past a little further. So when Paul D, the last of Sweet Home man shows up at the porch of 124, Sethe invites him at once to stay with her. Paul D's touch of Sethe's tree-shaped back in the kitchen, together with his gentle caresses of her breasts, brings back to Sethe's memory the scene of being milked by the two nephews and being whipped for telling on them. Their sex upstairs makes them both remember how she and Halle have joined in the corn field, the consequent feast of ears of new corn damaged during the filed love-making, the wedding dress Sethe sewed "on the 
sly"(Morrison, 1987, p.11), the meeting between Sixo and the Thirty-Mile woman, etc. Life at the Sweet Home rolls out scene by scene as a result of the "communal telling" through sex between Paul D and Sethe. (Morrison, 1987, pp.11-25) It leads to the happy union of Paul D, Sethe and Denver at the "carnival festival"(Morrison, 1987, pp.18-19). More hopeful is the fact that the community is on the verge of withdrawing their punishment of Sethe for her infanticide because some of its members wave back to them when Paul D addresses them (Morrison, 1987, p.47).

Yet, the happy reunion achieved is soon consumed by the absence of Beloved. (Rushdy, 1998, pp.140-153) By driving away the baby ghost and chastising Sethe for over-protecting Denver (Morrison, 1987, p.45), Paul D rejects an essential part of Sethe's history under slavery and the freedom promised by the telling (Keizer, 1999; Morrison, 1993). Cultural rehabilitation based on such an absence is both unstable and incomplete. The "bird", if it were to live on, calls for a renewed telling to rid Sethe and Paul D's stories of their dullness and staleness.

In response to "Sethe's call" for new knowledge and real "grace" (Morrison, 1987, p.88), Beloved makes its appearance on the stump outside 124 the very day when Paul D, Sethe, and Denver go to the carnival, an occasion "when white folks make a spectacle of themselves (Morrison, 1987, p.48)" for the amusement of an all-black audience, which, Susan Corey (2000) believes, also constitutes "a prelude to the arrival of Beloved"(Corey, 2000, p.38). At the sight of Beloved, Sethe feels her bladder suddenly filled to its capacity and runs away to void endlessly just like the moment when Denver was born. An association with past makes Sethe believe that Beloved's magic appearance, together with her flood water, constitutes "another freak" that might be accepted by the carnival (Morrison, 1987, p.51). In other words, Sethe sees Beloved as a grotesque figure that will help her storytelling community temporarily "dethrone the ideal of white supremacy" and achieve for the moment a sense of subjectivity and identity (Corey, 2000, p.38).

As it turns out, Beloved lingers on at 124 and develops a strong taste for Sethe's past that is almost insatiable. She chews what Denver tells her about how Amy has helped Sethe with her birth, and asks for more. She develops a "peculiar devotion" to Sethe and draws Sethe to tell her first about her earrings then about her mother (Morrison, 1987, p.57). To Sethe's surprise, she can tell Beloved practically everything, even what she would previously be unwilling to tell or what she would deliberately choose to forget when asked by Denver. Although "every mention of past hurts", Sethe finds it an "unexpected pleasure" to talk about past in Beloved's presence, and as a result her broken self is gradually pieced together with each telling of the fragments of her past (Morrison, 1987, p.58).

With Beloved, Sethe and Denver construct a new community of storytelling. In spite of the fact that Sethe would later regard Beloved as her killed daughter reincarnated and consequently her dearest part not to be separated from her, the newly formed storytelling community extends beyond the family unit. On the one hand, Sethe tries to reason with Beloved apologetically that it was out of love that she killed her (Morrison, 1987, p.164), while Beloved mercilessly scolds Sethe for jumping into the sea and leaving her alone to suffer (Morrison, 1987, pp.214-217). In order to keep Beloved, Denver tries to tell everything she has heard, and Beloved in turn tells her that she comes out of water from under the bridge where dead men and women are packed together over her, and a man without skin calls her "Beloved" at night and bitch during the day. Here, Beloved is both the physical embodiment of Sethe's murdered daughter, and those thousands who died during the Middle Passage (Corey, 2000, p. 37).

Beloved's magic appearance results in a storytelling community that comprises all the members of the community living around 124 Blue Stone. On the one hand, Paul D is led to the "ocean-deep place he had once belonged to" (Morrison, 1987:264). The roaring voices conjured up by Beloved have compelled Stamp Paid to ponder over the fate of all those "black and angry dead" with their "undecipherable language" (Morrison, 1987, p.181, p.198). On the other hand, Beloved as a ghost taking bodily form spurs Ella and other community women into communal singing, a cultural tradition that "transcends the coherence of language" and "escape representation"(Conner, 2000, p.69). Under the spell of such singing, the official history is broken and Beloved disappears.

The communal awareness Sethe has nurtured in the process of appropriating the white language to revise the official record of the incident of infanticide has great significance to the cultural renewal for the black community living in post-bellum America. It challenges not only the starkness of official history, but also the culturally annihilating and economically exploiting policies implemented by the dominant white culture. With the past fully confronted and "family secret" completely revised, Sethe is able to lay her past down to aspire for a better future within the black community.

\section{COMMUNAL SINGING}

Baby Suggs is another figure who is actively involved in the renewal of Afro-American culture through building communal solidarity among the black people. After her arrival at Cincinnati, She becomes "an unchurched preacher, one who visits pulpits and opens her great heart to those who use it" (Morrison, 1987, p.87). She starts a cultural practice that sets out to free the whole black community, flesh and soul. Followed by every black man, woman and child who could make it through, Baby Suggs takes her great heart to the Clearing, where she leads the community to laugh, dance, cry, and sing, which liberates as a result every part of their body despised under slavery. As Sethe would later notice, the singing in the Clearing breaks "the back of the words" and returns her to the pre-linguistic era when there were only sounds that would prove undecipherable to her. It is the same sounds that Paul D finds difficult to pin down in Sixo's song. They point to African language(s) and culture(s) lost in the process of enslavement. They are both heart 
soothing and identity generating. (Morrison, 1987, p.222) And the scene of singing and dancing in the woods celebrates the spiritual values cherished in West African culture (Holloway and Demetrakopoulos, 1987, Rigney, 1991). Viewed thus, Baby Suggs is a cultural mother bent on leading the freed black community of 124 Blue Stone Street to live a new cultural life based on their African cultural traditions.

In spite of her failure to prevent the persecution inflicted on her granddaughter either by the covetous Schoolteacher or by her helpless but love-driven daughter-in-law Sethe, Baby Suggs also re-enacts the image of African "Great Mother". In Beloved, Baby Suggs is represented as a woman of extraordinary power capable of feeding the whole community by drawing solely on her own source. She is able to love and, in turn, commands the love of the whole community through her ritualistic preaching. Therefore, she is "the giver of both life and wisdom", and "the creative potential and the sacred aspect of nature itself” (Rigney, 1991, pp.68-69). For the black community in Beloved, Baby Suggs is a cultural ancestor that embodies the remnant values taken from West African culture.

Baby Suggs has the power both to create a new culture on the new land and to guide the cultural reconstruction for younger generations. Her body-celebrating preaching is a cultural practice that, to borrow Homi Bhabha (1994) words, "hybridizes West African traditional cultural values and Euro-American capitalist colonizing cultural values" (Bhabha, 1994, pp.1-18). She cherishes her traditional regard for her Afro-American community, but she has also unconsciously internalized the Emersonian liberalism about self-reliance. Her preaching in the Clearing is a combination of West African spiritual beliefs and European American Christian doctrines (Ochoa, 1999). In spite of the danger of being assimilated by the dominant white American culture, Baby Suggs' cultural maneuvers nurture a hope for a new culture that renews her traditional culture.

Baby Suggs' preaching shares the same characteristics and has the same effects with Sethe's linguistic appropriation. However, Morrison seems to tell us that black Americans should not only learn to appropriate the language that constitutes an essential part of the white supremacist culture but also other elements of white cultural traditions in their attempt to mobilize the majority of black people and create a distinct black American culture.

\section{CONCLUSION}

Whether it is Baby Suggs' preaching or Sethe's storytelling, we find that both of them take African traditions as a source for of inspiration. Both of them, however, aim for a departure from that tradition. Though not African by birth, Baby Suggs creates within the black community her own syncretic folk religious practice, based on both West African and Christian spiritual traditions. Her preaching internalizes certain Euro-American values by acting out as an economically successful Great Mother. Sethe's storytelling, too, bases itself on the traditional way of communicating and preserving knowledge within African communities. Yet, it is telling a new land experience and it is dominated by Beloved as an embodiment of African American experience of slavery. Therefore, while both have taken the "interrelationship between ancestors and the community as their philosophical underpinning"(Wardi, 2002), both have been influenced by the American experience of slavery.

The magic power of healing and regeneration promised by both strategies makes both Baby Suggs and Sethe extraordinary figures bent on dethroning the white authority and supremacy established by the dominant discourses (Corey, 2002; Keizer, 1999). The only difference lies between their strategies is the difference in the means each of them has chosen. To put it more specifically, Baby Suggs resorts to dancing and singing as an avenue to articulate her cultural concern whereas Sethe appeals to community storytelling as her means of cultural reconstruction.

By representing Baby Suggs as a figure being worn down by whiteness and black indifference after the infanticide, and Sethe a figure hopeful of recovery, Morrison seems to favor storytelling over music and dancing as means of cultural reconstruction. In 1984, Morrison (1984) expresses a similar idea in "Rootedness: Ancestor as Foundation": "For a long time, the art form that was healing for black people was music. That music is no longer exclusively ours. So another form has to take that place, and it seems to me that the novel is needed by African-Americans now in a way that it was not needed before."(Morrison, 1986, p.340) Taking this into consideration, black Americans should not, according to Morrison, rely solely on music for devices of cultural reconstruction. Rather, they should rely more on telling stories that are essentially black American. Afro-American storytelling, though rewriting white colonial history, has the strength of bringing people together to from a communal solidarity that is so essential to black American cultural rehabilitation. But, of course, music and dance will remain important to many black Americans, because, according to Morrison, what makes black American literature distinctively black is the presence of ancestor. Therefore, so long as music/dance connects with ancestry, it will play a similar role as storytelling while Afro-Americans strive for their cultural rehabilitation.

It must be noted here that both communal singing and storytelling point to languages that are neither sexist nor racist languages because they are generative of meaning and life for Afro-Americans. It is in this sense that communal singing and storytelling practiced by the black community border on the word-work the old woman in Morrison's "Nobel Lecture" generates. They are filled with languages invented in the new land and they join in the Afro-American cultural reconstruction the moment they are created. 
The authors wish to thank Professor Wang Labao, Dean of School of Foreign Languages, Suzhou Univeristy, China, for his sincere help and insightful suggestions during the working of this paper. This paper was supported in part by Jiangsu Government Scholarship for Overseas Studies, Jiangsu Province, China; Teaching and Research Fund, Jinjiang College, Jiangsu University, China (JJ08C034); Teaching and Research Fund, Jiangsu University, China (JGYB2009076; J08C034).

\section{REFERENCES}

[1] Bhabha, Homi. (1994). The Location of Culture. New York: Routledge.

[2] Conner, Marc C. (2000). The Aesthetics of Toni Morrison. Jackson: University Press of Mississippi.

[3] Corey, Susan. (2000). Toward the Limits of Mystery: The Grotesque in Toni Morrison's Beloved. In: The Aesthetics of Toni Morrison. Ed. Marc C. Conner. Jackson: University Press of Jackson.

[4] Fanon, Franz. (1997). On National Culture. In: Postcolonial Criticism. Eds. Bart Moor-Gilbert and Gareth Stanton. London and New York: Longman

[5] Holloway, Karla F. C., and Stephane Demetrakopoulos. (1987). New Dimensions of Spirituality: A Biracial and Bicultural Reading of the Novels of Toni Morrison. New York: Green Wood Press.

[6] Keizer, Arlene R. (1999). Beloved: Ideologies in Conflict, Improvised Subjects. African American Review, 33, Spring: 105-123.

[7] Morrison, Toni. (1987). Beloved. New York: Alfred A. Knopf.

[8] Morrison, Toni. (1993). Nobel Lecture. www.nobel.se/literature/laureates/1993/morrison-lecture.html.

[9] Morrison, Toni. (1986). Rootedness: The Ancestor as Foundation. In: Black Women Writers: A Critical Evaluation. Ed. Mary Evans. New York: Anchor P/Doubleda.

[10] Ochoa, Peggy. (1999). Morrison's Beloved: Allegorically Othering: ‘White' Christianity. MELUS, Summer: 107-123.

[11] Rigney, Barbara Hill. (1991). The Voice of Toni Morrison. Columbus: Ohio State University Press.

[12] Rushdy, Ashraf H. A. (1998). Daughters Signifyin(g) History: The Example of Toni Morrison's Beloved. In: Toni Morrison. Ed. Linden Peach. New York: St. Martin's Press, 37-66.

[13] Rushdy, Ashraf H. A. (2001). Remembering Generations: Race and Family in Contemporary African American Fiction. Carolina: University of North Carolina Press.

[14] Schur, Richard. (2000). The Subject of Law: Toni Morrison, Critical Race Theory, and the Narration of Cultural Criticism. $49^{\text {th }}$ Parallel, 6, 455-476.

[15] Wardi, Anissa J. (2002). Inscriptions in the Dust: A Gathering of Old Men and Beloved as Ancestral. African American Reviews $36.1,35-54$.

Weiqiang Mao, born on September 15, 1976, China, is a PhD Candidate for Literature at Shanghai International Studies University. His major field of study is African American fiction and English Romantic poetry.

$\mathrm{He}$ is also a lecturer teaching at School of Foreign Languages, Jiangsu University, China. His recent publications include "Teaching Culture within and beyond Language" (English Language Teaching, 2009(4): 144-148), "Beloved as an Oppositional Gaze" (English Language Teaching, 2009 (3): 26-34), and "Give the Screw another Turn-A Cultural Re-Reading of The Turn of the Screw" (Journal of Language Teaching and Research, 2010, Vol.1.1)

Mr. Mao is a member of the National Association of British Literature, China. He was awarded Jiangsu Government Scholarship for Overseas Studies in 2009 and Excellent Teaching and Research Award of Jiangsu University in 2007 and 2009. 